Research Article

\title{
An Immersive Context Teaching Method for College English Based on Artificial Intelligence and Machine Learning in Virtual Reality Technology
}

\author{
Li Ma \\ Foreign Languages School, East China Jiaotong University, Nanchang 330013, Jiangxi, China \\ Correspondence should be addressed to Li Ma; 57627550@qq.com
}

Received 7 July 2021; Revised 30 July 2021; Accepted 7 August 2021; Published 13 August 2021

Academic Editor: Sang-Bing Tsai

Copyright (c) $2021 \mathrm{Li} \mathrm{Ma}$. This is an open access article distributed under the Creative Commons Attribution License, which permits unrestricted use, distribution, and reproduction in any medium, provided the original work is properly cited.

\begin{abstract}
With the development of language research and language teaching, people realize that grammatical competence is an important part of communicative competence. In foreign language teaching, grammar teaching is not only necessary but also the main way to achieve the goal of communicative competence. This article mainly studies the virtual reality technology college English immersive context teaching method based on artificial intelligence and machine learning. The purpose is to improve students' English learning ability. Through the comparative teaching experiment of two classes of freshmen in a university, the experimental class conducted VR technology-based immersive virtual context teaching from the perspective of constructivism, while the control class adopted common multimedia equipment and traditional teaching methods. In the classroom, teachers occupy most of the time, students only passively receive a lot of information from teachers, they have little chance to participate in the exchange of information and express ideas in the target language, and most of the time they are "immersed" in the Chinese environment. The overall English level was also better than that of the control class, with an average score of 2.8 points higher. This shows that college English immersive context teaching combining constructivism theory and VR technology can indeed improve students' English level.
\end{abstract}

\section{Introduction}

With the continuous improvement of the degree of internationalization, English as the universal language, its practicality has gained increasing attention, especially in countries where English is the second language [1]. Therefore, it is necessary to create simulation scenarios, improve the classroom teaching environment, and let learners immerse themselves in the simulation language environment. Zhang discussed the basic elements. The sample size of his study was small and not representative. Compared with the traditional multimedia-assisted teaching method, Zhonggen studied whether using an answering machine could improve learners' English level. Finally, the final result was analyzed through the comparison of three questionnaires. Peng proposed an innovative comprehensive teaching model and teacher (BEST) teaching model based on the big data environment and put forward a college English-teaching model [2]. Although big data are representatives, education focuses on teaching students according to their aptitude. Each student's situation is not the same. Based on the constructivism theory, it innovatively introduces VR technology into college English teaching and proposes a new immersive virtual-situation teaching method. Students and teachers studied in groups in a virtual situation created by VR technology and communicated in English throughout the whole process [3]. All students were given an English test and a questionnaire. The result of the questionnaire shows that the experimental class is more satisfied with their grades than the control class, and most students prefer the new teaching method. In this study, the concept of space in mathematics is introduced into the field of linguistics, which provides us with enlightenment for the study of immersion teaching strategy in classroom teaching. 


\section{Immersion Context Teaching Method of College English}

\subsection{Teaching under the Theory of Constructivism}

2.1.1. Constructivism Learning Theory. The constructivism view of knowledge holds that knowledge does not absolutely and objectively reflect the reality and is not the final answer to the problem, but the explanation, hypothesis, or hypothesis of the objective world will get new answers with the deepening of people's understanding. Textbook science does contain truth, but it is by no means the final answer. Teaching is not to infuse knowledge to students [4], but to guide students to receive knowledge, construct knowledge, and analyze the rationality of knowledge from their own experience and background.

The constructivism learning view holds that the learning process, on the one hand, constructs new information, and on the other hand, reorganizes the original learning experience. Learning and understanding of any subject must be based on the learner's previous knowledge and experience, including informal learning and everyday concepts before learning scientific concepts, that is, on the learner's original cognitive structure. Instead of passively receiving information stimuli, learners actively construct meaning. According to their own knowledge and experience, learners actively filter and process external information to obtain their own meaning. For the same external stimulus, different learners have different screening, processing, and coding methods for new information due to different original knowledge and experience [5], leading to different understandings. Context teaching is the method of following and using context theory to organize teaching. The context teaching method has the characteristics of vivid, associative, and restrictive. Authenticity refers to the social classroom and communication authenticity. Students are placed in a real environment for communication and participate in various language activities as members of the real society. Association refers to the context teaching method which can make students produce memory association. The context teaching method enables students to accept and use language knowledge in the communicative environment, which will provide clues for students to remember the language knowledge, such as scenes, characters, and plots, to facilitate the long-term retention of students' memory. Restrictive refers to the context which generally restricts the content of language activities, the choice of vocabulary, and the sentence structure.

Constructivism view of students holds that teachers are the presenters of knowledge, but this does not mean that teachers are the authorities of knowledge and cannot impose their own knowledge understanding on students. Teachers must pay attention to students' own knowledge understanding because knowledge is derived from students' own knowledge structure and belongs to them. Teachers can only instruct students to adjust or enrich their understanding. Students should not passively receive new knowledge; they are the subject of new knowledge processing and meaning construction. Therefore, teaching must be student-centered and teacher-led, enabling students to learn independently.
2.1.2. Teaching Method Based on Constructivism Learning Theory. Its teaching link includes the following points. Independent exploration: students independently explore various attributes related to a particular concept. Collaborative learning: it includes group discussion [6].

Anchored instruction is based on real events or problems and includes the following points. Create situation: students learn in the same or similar situation to the reality. The learning process of anchored instruction is the process of solving problems, so the learning effect of students is directly reflected in this process [7].

In random access to teaching, each entry has a different learning purpose and focus so that learners can gain a leap in understanding things, and its teaching links include the following points. Present basic situation: it presents the situation related to the basic content of the current learning topic to the students and enters the learning at random. Group collaborative learning: it is group discussion around the knowledge acquired in different situations [8].

\subsubsection{Teaching Design Principles Based on Constructivism} Learning Theory. Emphasize the importance of "context" to mean construction. In actual learning, learners can assimilate new knowledge to their original relevant experience, thus giving the new knowledge some meaning. If they cannot assimilate, "adaptation" will be caused and the original cognitive structure will be reconstructed [9].

Through collaborative learning, the thinking and wisdom of the learner group can be shared by the whole group, and the whole group of learners can jointly complete the construction of the meaning of the learned knowledge $[10,11]$.

It emphasizes the design of the learning environment; learning should be promoted and supported, not controlled strictly; the learning environment should be a place to support and promote learning. Students' independent exploration, collaborative learning, and teachers' guidance should all focus on "meaning construction" $[12,13]$.

\section{VR Technology in Teaching}

\subsection{Classification of VR System}

3.1.1. Features of VR Technology. In the virtual scene designed in this way, the goal is generally conceptualized [14]. For example, the use of VR technology in military, medical, education, and other fields can more appropriately solve the current problems. Developers can develop software according to the needs of users $[15,16]$.

3.1.2. Situational Teaching Based on VR Technology. The first is virtuality. VR technology supports education that can simulate everything [17]. What students are exposed to in the practice process is generated by VR technology simulation, which can ensure the safety of students. Second is practicality. Situational teaching based on VR technology attaches great importance to students' practical ability [18]. In the daily educational activities, students' activities are 
limited to several places, and the space is limited. The teaching methods and experience method are different from the previous education, and the students' experience is also different from the past. Third is life. The design principle of situational teaching based on VR technology is to be close to reality and not far away from students' cognitive development.

The basic requirements of VR-based situational teaching include [19] hardware equipment, including computer hardware, application, software, VR glasses, and gamepad operators; on the basis of adequate hardware and equipment, teachers should be skilled in using VR technology. Meet the training objectives and design and implement according to the curriculum standards. Acceptability: the teaching content must be within the acceptable range of students, and the situation design must be close to students' reality and conform to the curriculum standards [20].

The advantages of situational teaching based on VR technology include diverse modes, which are conducive to expanding students' innovative thinking; the content is real and the teaching situation is more visualized; repeat experience to reduce the impact of the teaching environment [21].

\subsection{Development of Immersion Teaching Methods}

3.2.1. The Principle of Immersion Teaching. Immersion teaching originated from French teaching in Canada and has been widely used in second language teaching [22].

The school curriculum provides a basic environment for learning a second language and provides students with the opportunity to communicate in a second language. Therefore, in the process of learning, cognitive and communicative competence will develop along with the development of language [23]. Therefore, second language immersion teaching is a teaching mode of students' unconscious choice, which integrates pedagogy, psychology, and linguistics.

3.2.2. Immersion Teaching Strategy. In this way, teachers can pay attention to the learning situation and response of most students in teaching activities, accurately adjust the degree and difficulty of language input [24], provide an appropriate amount of language input, and encourage students' learning enthusiasm when teaching in a simple and understandable way.

In a relaxed and pleasant environment, students learn through observation, repetition, memory, and imitation. Combining the listening and speaking materials, the listening and speaking method and the communication method are used, through continuous contact with the real context.

Give play to the role of students as the main body. In teaching, teachers should not only encourage students to imitate boldly but also encourage students to ask questions boldly, participate in activities in each teaching link, form a positive teacher-student interaction, create a good teaching atmosphere, and mobilize and maintain students' interest and enthusiasm in learning [25].
3.2.3. Principles of Immersion Teaching Method. All English teaching principles: due to the positive and negative transfer of the mother tongue, most learners will apply the language habits, methods, meanings, and forms of the mother tongue when learning English, which causes certain difficulties in English learning. Full English immersion teaching provides students with a wealth of target language input frequencies and opportunities. The input of the target language converts the second language into internal output as much as possible, which marks the acquisition of the second language by students [26]. In the whole teaching process, teachers always use English as the carrier of teaching to provide an all-English atmosphere so that students develop the habit of thinking and solving problems in English.

In the interactive process, teachers' explanations and students' questions cross. In addition to participating in it, teachers should always encourage students to overcome their shyness and tension, create a student-centered independent learning environment, and encourage students to construct their own knowledge structure in learning [27].

\subsubsection{Artificial Intelligence and Machine Learning.} Machine learning is to use system data and data analysis results to reorganize the existing knowledge structure to improve its performance as an experience. Machine learning is one of the most important research fields of artificial intelligence technology. An intelligent system without any learning ability cannot be called a real intelligent system. Machine learning has a profound impact on all walks of life, especially in the field of education. In addition, the main task of machine learning is to do data analysis, that is, data mining. For example, the machine can mine valuable data by analyzing the total data of a student's learning situation in various disciplines in the past year and can effectively analyze the causes of the students' learning problems and put forward corresponding learning suggestions.

English teaching activity is a complex process, which also contains many uncertain factors, such as language teaching, software and hardware environment, English teachers' professional level, students' interest state, cognitive style, and teaching and learning style. The biggest feature of AI is that it can simulate human thinking mode and reproduce the process of thinking solution and reasoning. The complexity of English teaching process requires AI to play its unique solving strategies to help specify dynamic teaching strategies suitable for each student.

\section{Experiments between the New Teaching Method and the Traditional Teaching Method}

4.1. Experimental Subject. The research objects of this experiment are freshmen from class 1 and class 2 of economics major in a university. There are 67 students in both classes, 34 students in Class 1, and 33 students in class 2. The ratio of boys and girls in the two classes is relatively balanced, and there is not much difference in average English scores. 
TABle 1: Sample data.

\begin{tabular}{lccc}
\hline Age range & Man & Woman & Total \\
\hline$\leq 17$ & 9 & 11 & 20 \\
18 & 15 & 22 & 37 \\
19 & 4 & 3 & 7 \\
$\geq 20$ & 2 & 1 & 3 \\
Total & 30 & 37 & 67 \\
\hline
\end{tabular}

Note: $X^{2}=0.591 ; P=0.623$

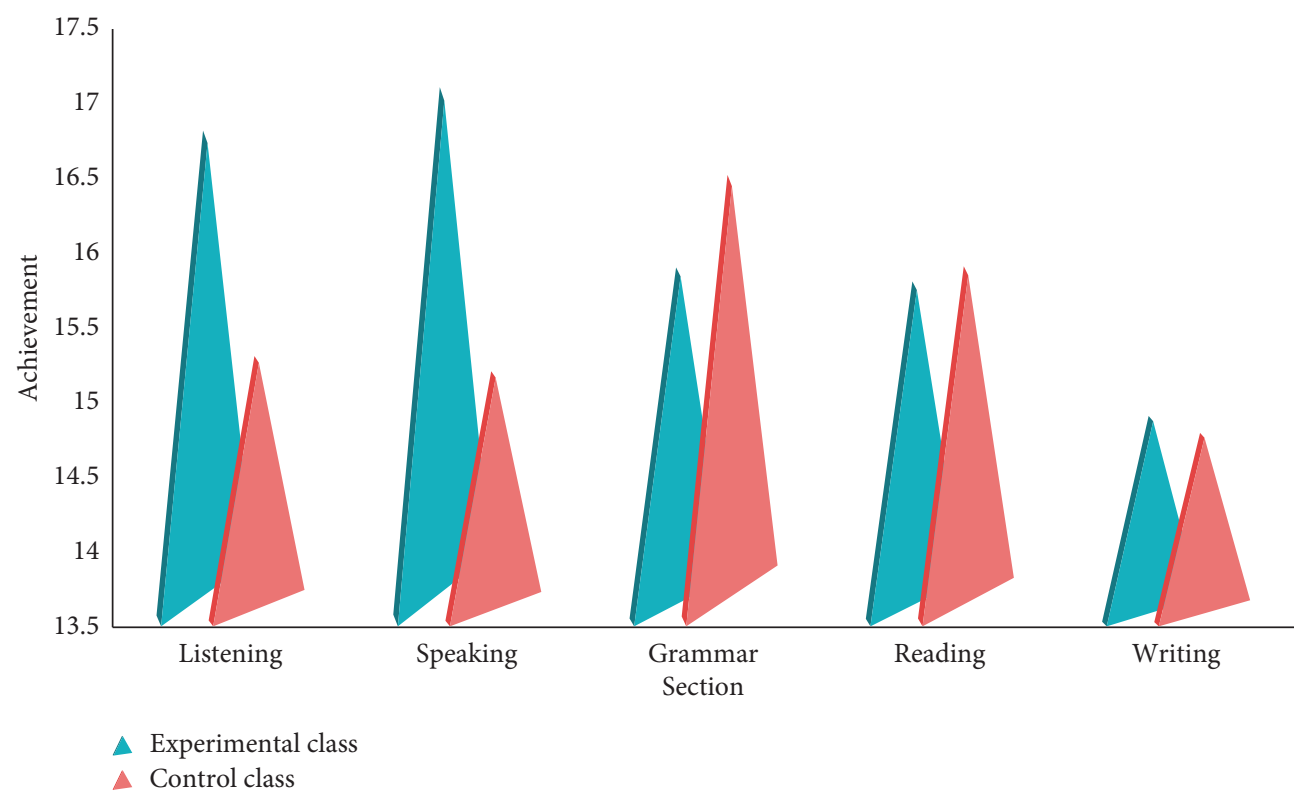

Figure 1: Comparison of grades between the two classes.

The sample data are shown in Table 1 . There are 30 boys and 37 girls in the two classes. The largest number of boys and girls are aged 18 , followed by 17 or below.

4.2. Experimental Methods and Procedures. First, make some preliminary preparations, formulate teaching plan steps based on constructivism theory, communicate with teachers in advance, and clarify the basic tasks, teaching points and difficulties, and teaching activities; select the appropriate VR software and scene in combination with the content of the lecture; before the beginning of the course, the students of the experimental class were trained on the operation of VR equipment.

The comparative teaching experiment was conducted between the two classes. Class 1 is an experimental class, which carries out English immersion teaching combining constructivism and VR technology for one semester. Teachers will make comments during the discussion to enhance students' understanding of knowledge. Class 2 is a control class, which uses conventional teaching methods and teaches by traditional equipment such as blackboard, PPT slides, and videos. The teaching process of the two classes is consistent with the teaching content, and the same teacher teaches.

Each class has three classes a week. At the end of a semester's teaching, the two classes are given the same
English test. The $Z$-test of significance of achievement difference used is shown in formula,

$$
Z=\frac{\overline{x_{a}}-\overline{x_{b}}}{\sqrt{\left(s_{a}^{2} / n_{a}\right)+\left(s_{b}^{2} / n_{b}\right)}}
$$

where $\overline{x_{a}}$ and $\overline{x_{b}}$ are the average scores of the experimental group and the control group.

Then, all students were investigated by questionnaires, and different questionnaires were designed for different classes to ensure a reasonable structure and strong logic. The questionnaire design is easy to understand, which reduces the use of professional terms, reduces the embarrassed mood of interviewees, and reduces the skills of asking sensitive questions. Reasonable design of the number of questions improves the efficiency of the questionnaire and the questionnaire time within 20 minutes.

\section{Discussion on the Effect of Immersion Teaching Methods Combined with Constructivism and VR Technology}

5.1. Test Score Comparison. After a semester of different teaching, the two classes were given a final English test covering listening, speaking, grammar, reading, comprehension, and writing. Each section is worth 20 points for a 


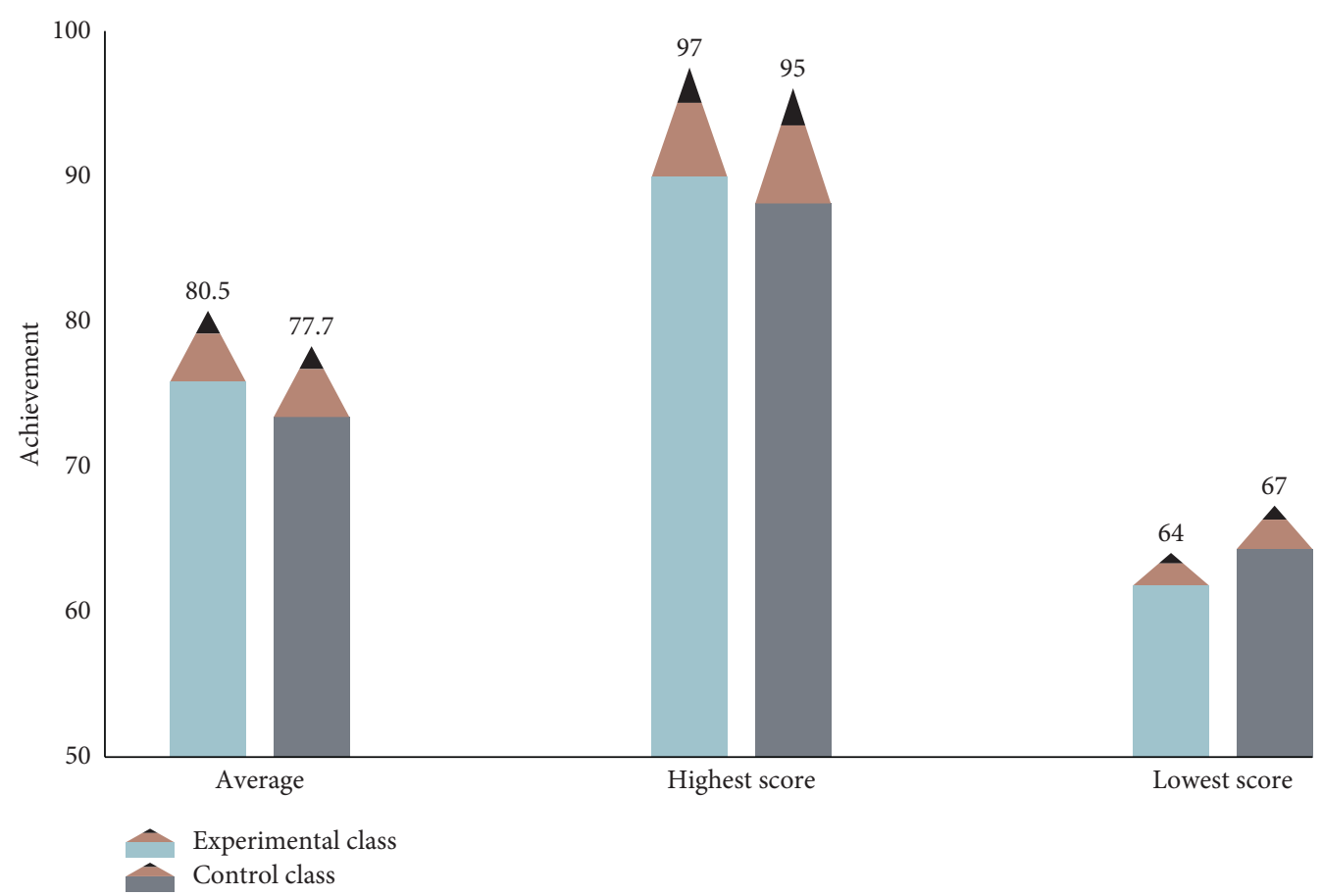

FIgURE 2: Comparison of the average score, the highest score, and the lowest score of the two classes.

TABLE 2: Students' adaptation to VR immersion teaching in the experimental class.

\begin{tabular}{lcccc}
\hline Degree & Complete adaptation & Adaptable & Need time to adapt & Hard to adapt \\
\hline Number & 5 & 16 & 8 & 5 \\
\hline
\end{tabular}

total of 100 points. Record the score of each part and calculate the average score.

It can be seen from Figure 1 that the listening and speaking scores of the experimental class are much higher than those of the control class. On the whole, the average score of the writing score in the experimental class is slightly better than that in the control class, which may be due to solid conversational ability and excellent language sense.

As shown in Figure 2, the experimental class was 2.8 points higher than the control class. This suggests that VR immersion can improve overall performance, but not for individual students.

5.2. Questionnaire Results. After the end of the final test, a survey, using a questionnaire, for the 34 students in the experimental class was conducted to investigate whether the students could adapt to VR immersion teaching.

As shown in Table 2, the number of students who fully adapt to the VR immersion teaching method is the same as that of those who find it difficult to adapt, both 5. Among them, most students can adapt to the teaching method, accounting for $47.1 \%$ of the whole class.

As shown in Figure 3, of the 33 students in the control class, only 7 students have a certain understanding of VR technology, but they may not have used it. Among them, $64 \%$ students' understanding of VR technology is only

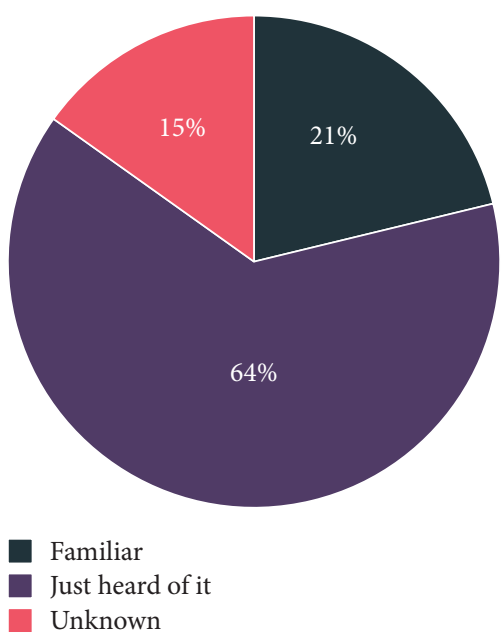

FIgURE 3: Students' understanding of VR technology in the comparison class.

limited to hearing about it. If it is to be applied in the field of education, the popularization of relevant knowledge should be strengthened.

Although the objects of the two questionnaires are different, both of them have investigated the students' satisfaction with their own academic performance in order to judge the students' satisfaction with their own learning under different teaching methods. 


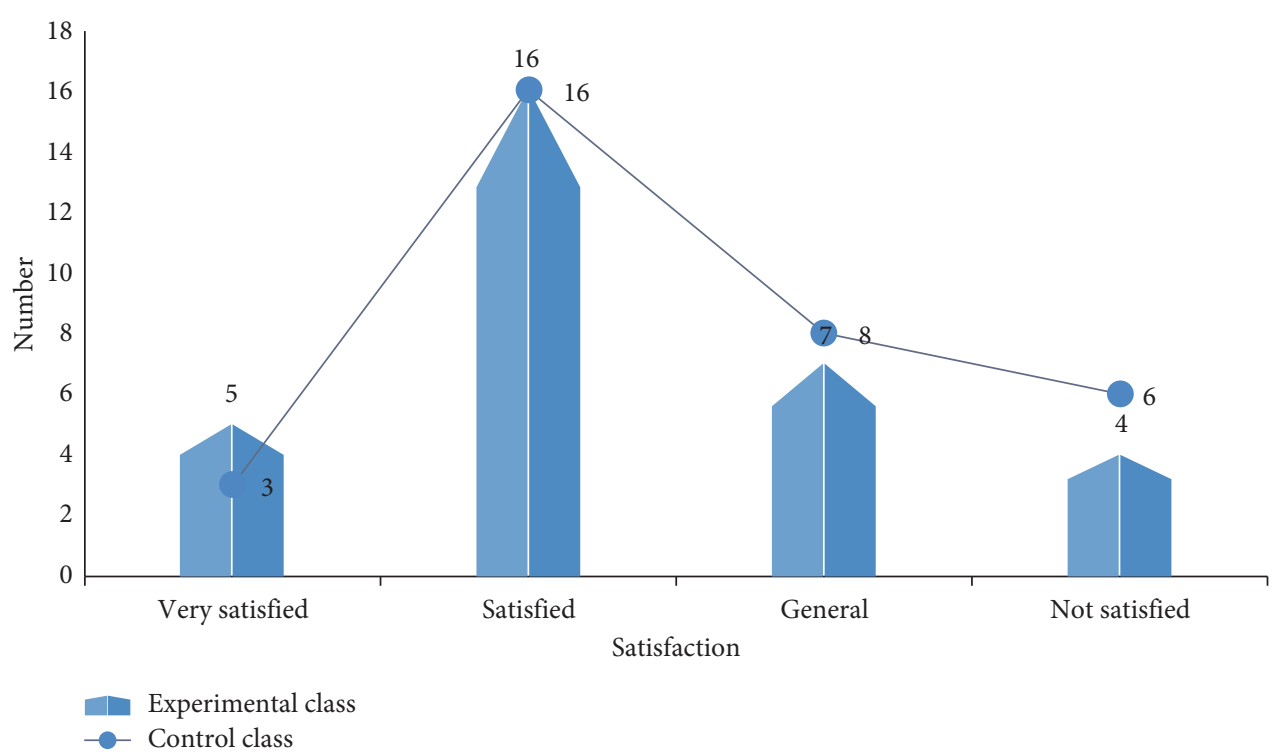

FIGURE 4: Students' satisfaction with their grades in the two classes.

As shown in Figure 4, there was not much difference in the number of students who thought their grades were average. This indicates that no matter which class they are in, most students have high requirements on themselves and hope to have better development in English learning.

\section{Conclusions}

Constructivism is a scientific teaching theory, which has become the theoretical basis of teaching with its unique view of knowledge, learning, and students and has provided theoretical guidance for many teachers' teaching work. Education and teaching methods also need constant innovation. VR technology, as an emerging technology introduced in the field of education, can well help teachers carry out immersion teaching. The virtual situation created by VR technology breaks the time and space limit and enables students to learn new knowledge in a new "real" environment. From the perspective of students majoring in modern educational technology and taking the overall development of middle school students as the fundamental starting point and destination, this paper explores the application of AI in middle school English teaching, including the possible utility and deficiency of AI in middle school English teaching.

In English immersion teaching, constructivism provides the theoretical basis and VR technology provides the technical support. For college students with strong comprehension ability, the acceptance difficulty of English teaching is relatively low. In digital narration and expression, students should tell and share their thoughts and insights in English through video, audio, text, emoticons, and other carriers, while others can participate in, supplement, improve, and evaluate students' narration. In this process, both the narrator and the audience can flexibly use the learned English knowledge, and the participation and cooperation of other students can also play a role of feedback and correction, to strengthen the learning effect.
This study only takes students of one major as the research object for experimental research, without fully considering that students of different majors have different logical thinking modes. Therefore, in the following research work, the author will increase the sample size and type of the research objects.

\section{Data Availability}

The data that support the findings of this study are available from the corresponding author upon reasonable request.

\section{Conflicts of Interest}

The authors declare that they have no conflicts of interest.

\section{References}

[1] O. A. Oyewunmi, A. I. Taleb, A. J. Haslam, and C. N. Markides, "On the use of SAFT-VR mie for assessing large-glide fluorocarbon working-fluid mixtures in organic Rankine cycles," Applied Energy, vol. 163, no. Feb.1, pp. 263-282, 2016.

[2] Z. Lv, R. Lou, J. Li et al., "Big data analytics for 6G-enabled massive internet of things," IEEE Internet of Things Journal, vol. 8 , no. $7,2021$.

[3] Z. Lv, X. Li, and W. Li, "Virtual reality geographical interactive scene semantics research for immersive geography learning," Neurocomputing, vol. 254, pp. 71-78, 2017.

[4] G. Saposnik, L. G. Cohen, M. Mamdani et al., "Efficacy and safety of non-immersive virtual reality exercising in stroke rehabilitation (EVREST): a randomised, multicentre, singleblind, controlled trial," The Lancet Neurology, vol. 15, no. 10, pp. 1019-1027, 2016.

[5] M. Chen, W. Saad, and C. Yin, "Virtual reality over wireless networks: quality-of-service model and learning-based resource management," IEEE Transactions on Communications, vol. 66, no. 11, 2017.

[6] K. Gamage, "The pedagogical application of the grammar translation method as an effective instructional methodology 
in teaching English as a second language," Open Access $\mathrm{Li}$ brary Journal, vol. 7, no. e6913, pp. 1-10, 2020.

[7] M. Ben El Moudden, "The integration of games in teaching English as a foreign language in the classroom: moulay ismail university as a case study," International Journal of Language and Literary Studies, vol. 3, no. 1, pp. 208-229, 2021.

[8] N. Sidash, M. Roganova, V. Domina, L. Victorova, M. Roganov, and V. Miroshnichenko, "Pedagogical consciousness formation of future university educators in the process of teaching English," Universal Journal of Educational Research, vol. 8, no. 4, pp. 1202-1211, 2020.

[9] L. R. Sharma and R. N. Khanal, "Effectiveness of lecture and discussion teaching methods in teaching English language through figures of speech," Journal of Advanced Academic Research, vol. 6, no. 1, pp. 1-17, 2019.

[10] Y. Alhasov, A. Verbytska, and T. Kolenichenko, "Teaching English to adult learners within extracurricular activities at university: barriers and motivation factors," Advanced Education, vol. 7, no. 15, pp. 12-19, 2020.

[11] F. Orabueze, H. I. Okafor, U. U. Okonkwo, M. M. Chinonso, and O. Ekwueme, "Methods and techniques of teaching English and German classes in Nigeria during the Covid-19 pandemic era," XLinguae, vol. 14, no. 1, pp. 91-99, 2021.

[12] S. A. Yusupova, "Ways to develop the use OF trios IN teaching English IN the educational process (ON the example OF reading, writing and listening)," Theoretical \& Applied Science, vol. 84, no. 4, pp. 652-654, 2020.

[13] I. Vldescu, "An experiment on teaching English as a foreign language in Romanian schools using mastery learning strategies," Journal of Education in Black Sea Region, vol. 6, no. 1, pp. 79-96, 2020.

[14] L. Nguyen, "Vietnamese EFL teachers' beliefs and practices of alternative assessment in teaching English at secondary school," Asian EFL Journal, vol. 24, no. 2, pp. 31-57, 2020.

[15] T. B. Tenridinanti, "The impact of a brief teaching English towards the drivers online transportation in dealing with ASIAN GAMES 2018," International Journal of Psychosocial Rehabilitation, vol. 24, no. 1, pp. 1944-1949, 2020.

[16] Y. Macías and J. S. Villafuerte, "Teaching English language in Ecuador: a review from the inclusive educational approach," Journal of Arts and Humanities, vol. 9, no. 2, pp. 75-90, 2020.

[17] K. Akhmadjonova and Y. S. Sotimboyeva, "Using a computer and the role of computer programs in teaching English to preschoolers," Theoretical \& Applied Science, vol. 84, no. 4, pp. 727-730, 2020.

[18] U. B. Jaya, C. S. Shelly, I. Nuraida et al., "An analysis of teacher pedagogical competence in teaching English at SMK PGRI 3 kota serang," Journal of English Language and Literature, vol. 3, no. 1, pp. 54-66, 2020.

[19] M. M. Ali and M. O. Hamid, "Teaching English to the test: why does negative washback exist within secondary education in Bangladesh?" Language Assessment Quarterly An International Journal, vol. 17, no. 2, pp. 1-18, 2020.

[20] N. Ali, "The effect of using technology-enhanced English course (TEEC) in teaching English as a foreign language at preparatory schools," International Journal of Psychosocial Rehabilitation, vol. 24, no. 5, pp. 2658-2666, 2020.

[21] A. D. Sh, "Technologies of using "communicative training" in teaching English to 9-11th grade students in secondary schools," Turkish Journal of Computer and Mathematics Education (TURCOMAT), vol. 12, no. 3, pp. 3120-3125, 2021.

[22] M. Toya, "Exploring the process of teacher development toward teaching English by using the trajectory equifinality modelling approach: elementary, middle and high school comparison," Impact, vol. 2020, no. 9, pp. 35-37, 2020.

[23] J. Grubor, "Beyond teaching English: EFL students' accounts of learning outcomes in a cooperative class," Naucne publikacije Drzavnog univerziteta u Novom Pazaru. Serija B, Drustvene \& humanisticke nauke, vol. 3, no. 2, pp. 80-95, 2020.

[24] Y. Rosalinah and N. Khilda, "Teaching English speaking through information gap technique (a classroom action research at the 8th grade students of madrasah tsanawiyah Alhusna depok)," Wanastra: Jurnal Bahasa dan Sastra, vol. 11, no. 2, pp. 159-166, 2019.

[25] I. Ostroverkhaia and N. Andreeva, "Adaptation possibilities of the "chain» instructional technique realized through teaching English at non-lingustic university," Lifelong education: The XXI Century, vol. 28, no. 4, pp. 61-73, 2019.

[26] S. Supiani, "Investigating the efl teachers' attitudes toward the integration of web 2.0 tools in teaching English at islamic boarding schools," Wiralodra English Journal, vol. 3, no. 1, pp. 272-285, 2019.

[27] M. Siregar, "Model of translation textbook for teaching English as foreign language (TEFL) pedagogical purpose," SALTeL Journal (Southeast Asia Language Teaching and Learning), vol. 2, no. 2, pp. 72-82, 2019. 